\title{
Design for Manufacturing and Assembly: A Method for Rules Classification
}

\author{
Claudio Favi ${ }^{1(\otimes)}$, Marco Mandolini ${ }^{2}$, Federico Campi $^{2}$, Paolo Cicconi $^{3}$, \\ Roberto Raffaeli ${ }^{4}$, and Michele Germani ${ }^{2}$ \\ 1 Università degli Studi di Parma, Parco Area delle Scienze 181/A, 43124 Parma, Italy \\ claudio. favi@unipr.it \\ 2 Università Politecnica delle Marche, Via Brecce Bianche, 60131 Ancona, Italy \\ 3 Università degli studi ROMA3, Via della Vasca Navale, 79, 00146 Roma, Italy \\ ${ }^{4}$ Università degli studi di Modena e Reggio Emilia, Via Amendola 2, \\ 42122 Reggio Emilia, Italy
}

\begin{abstract}
The paper provides a method to acquire, process, and represent DfMA rules to help designers and engineers in the development of mechanical products compliant with manufacturing and assembly technology. This research work wants to define a general method able to link DfMA design guidelines (knowledge engineering) with geometrical product features that are available by the investigation of the 3D model. Numerical parameters of design features are related to design guidelines for the identification of manufacturing and assembly issues within the analysis of the 3D model.
\end{abstract}

Keywords: DfMA · Design rules · Embodiment design $\cdot$ Knowledge formalization $\cdot$ Mechanical products

\section{Introduction}

Product Development Process (PDP) is a consolidated engineering activity that takes a product from conception to market. The steps in product development include drafting the concept, creating the overall design, developing detail design, and prototyping $[1,2]$. One of the most recurring disciplines in the engineering design contexts relates the solid modelling and drawing (CAD - Computer-Aided Design). Nowadays, CAD tools couple the initial capability for which they were conceived, with the potentialities deriving from the integration of the multidisciplinary design methodologies (i.e., FEM, CAM) [3]. Design for $\mathrm{X}$ (DfX) is a target design methodology that gives designers a thought process and guidance for developing products oriented to a specific engineering challenge (i.e., manufacturability, assemblability, sustainability) [4]. For example, Design for Assembly (DfA) is a systematic procedure aiming at the reduction of assembly time through the reduction of the overall number of components in a given assembly [5]. At the same time, Design for Manufacturing (DfM) is an engineering practice aiming at the simplification of the manufacturing process for cost reduction of a given component [6]. DfMA (Design for Manufacturing and Assembly) is considered a comprehensive engineering practice

(C) The Author(s) 2021

L. Roucoules et al. (Eds.): JCM 2020, LNME, pp. 354-359, 2021.

https://doi.org/10.1007/978-3-030-70566-4_56 
integrating manufacturing and assembly aspects. DfMA is a design methodology that suffers a real integration with 3D CAD systems. In particular, DfMA principles are currently applied downstream of the 3D modelling following available knowledge from the literature and the company's know-how (internal knowledge) [7]. Literature provides several attempts with regards to DfMA knowledge formalization using ontologies [8,9]. Within the design context, the need to create a conceptual framework for data exchange is amplified by the nature of design information, which ranges from geometric descriptions of the part itself to manufacturing information such as material and cost. Ontologies overcome this limitation since their focus is not only on data or knowledge but also on the information context that lets specific access to detailed information parts to a latter phase [10]. However, the link with product analysis for geometrical features modification is still a grey area with possible potential for research activities. The goal of the paper is to provide a method that helps designers in the collection of DfMA design rules oriented to product manufacturing and assembly. In particular, this research work wants to define a general method able to link DfMA design guidelines (knowledge engineering) with geometrical product features that are available by investigating the $3 \mathrm{D}$ model. This method is leading to the development of a knowledge-based management tool that is accessible to designers for design updates. Numerical parameters of design features are related to design guidelines for the identification of manufacturing and assembly issues within the analysis of the 3D model. The novelty of this work is beyond the simple collection of DfMA rules by using an ontology method. The paper allows creating a list of design rules that can be integrated into a $3 \mathrm{D}$ system for the investigation of manufacturing and assembly issues early in the design step. The paper is structured as follows: after this introduction, Sect. 2 describes the knowledge-based system used for the classification of the DfMA rules, and Sect. 3 reports a case study of DfMA rule classification. Section 4 presents the concluding remarks and future perspectives on this subject.

\section{Materials and Methods}

A knowledge-based (KB) system is used for the classification of DfMA rules. The method for the classification of DfMA rules is grounded on three main pillars: (i) knowledge acquisition, (ii) knowledge processing, and (iii) knowledge representation. Knowledge acquisition refers to the literature analysis and industry best practices investigation for the collection of DfMA design rules. In particular, this phase is characterized by two main tasks: (i) collection of design rules for different manufacturing and assembly technologies (text), and (ii) identification of geometrical entities and numerical parameters involved in the design rules (numerical data). Knowledge processing refers to the link between the DfMA design rules previously collected within the knowledge acquisition phase and the geometrical features of a virtual 3D model. This phase is an essential task to transform a checklist (DfMA rules list) into a systematic design review of the product under development (3D model). Knowledge representation refers to the definition of a structured repository for the collection and the elicitation of DfMA knowledge. This phase encompasses the logical definition of DfMA design guideline (syntax) and all the necessary information to store within the repository, including example about possible changes to guarantee product manufacturability and assemblability. 


\subsection{Knowledge Acquisition Phase}

Knowledge acquisition phase starts with the analysis of the literature (e.g., book, research papers, technical reports, master and Ph.D. thesis) related to the DfMA topic. In particular, in this research work, the following books were analyzed and reported in the references section: (i) Boothroyd et al., [11], (ii) Bralla [12], (iii) Caimbrone [13], (iv) Poli [14], and (v) El Wakil [15]. In some references, DfMA rules are available as a list of actions. Designers should consider such rules during the design phase of a mechanical component subjected to a given technology. On the other hand, for some other books, the DfMA rules are not explicitly stated, and a deeper analysis is necessary to extract design rules. Another important source for the acquisition of DfMA rules concerns the use and access to the available documentation of commercial tools developed for DfMA analysis. For example, DFMA® tool, and DFMPro® are two software tools developed to help designers and engineers in developing assembly-compliant products. Besides, several meetings in design departments of mechanical industries permitted the collection of the best practices and rules dedicated to given manufacturing technologies.

\subsection{Knowledge Processing Phase}

The knowledge processing phase starts with the definition and classification of manufacturing technologies associated with a given DfMA rule. Classification of manufacturing technologies requires the characterization of different clusters: (i) Manufacturing technology class (i.e., machining, sheet metal stamping, metal forming, metal casting, plastic forming, welding, assembly), (ii) Manufacturing technology type - level I, and (iii) Manufacturing technology type - level II. These three groups are necessary to classify DfMA rules that are generic for a technology class or specific for a manufacturing type (operation). Indeed, a DfMA rule may be valid for a manufacturing technology class (i.e., machining) regardless of the specific operation (i.e., turning, milling, drilling). Conversely, a DfMA rule may be valid only for a specific operation (i.e., drilling) and cannot be generalized for the manufacturing technology class that contains the operation (i.e., machining). The two levels of manufacturing technology type allow classifying DfMA rules base on a list of operations (i.e., turning) or for a single operation (i.e., drilling, external cylindrical turning, internal cylindrical turning). After the definition of manufacturing technologies, the authors established a new classification method based on the material involved within the DfMA rule. Again, two different clusters have been defined: (i) material class, and (ii) material type. These two clusters permit allocating a given DfMA rule to a generic class of materials (i.e., stainless steel) or to a specific type (i.e., AISI 304). The last definition deals with 3D CAD features to recognize according to a given DfMA rule. Three clusters are necessary: (i) 3D CAD features to recognize, (ii) PMI - Product manufacturing Information to read, and (iii) Dimension/geometry. The CAD feature can be identified through different methods such as the 3D Convolutional Neural Networks proposed by Zhang et al. [16] allowing to learn machining features from CAD models of mechanical parts (Fig. 1). 

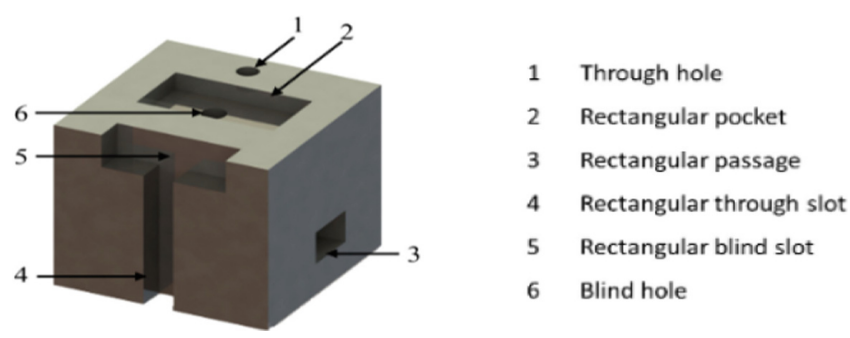

Fig. 1. Example of a 3D CAD feature recognition [16].

\subsection{Knowledge Representation Phase}

The knowledge representation phase starts with the definition of a structured form for a DfMA rule. Indeed, a guideline syntax is necessary to keep consistency among different guidelines and to provide the same level of details and information to a mechanical designer. DfMA guideline syntax requires necessary information and optional information. For example, necessary information provides the minimum set of information to perform a design improvement. Necessary information consists of: (i) the design action to do (verb), and (ii) the subject which requires modification (name). Optional information provides additional data that allow clarifying the context of the required design action. Optional information consists of: (i) the manufacturing process, (ii) the type of feature involved, (iii) the type/family part, and (iv) the type of material.

\section{Case Study: DfMA Rules Classification}

This section provides an example of the application of the proposed method in the development and classification of DfMA rules in machining technology. Figure 2 highlights the knowledge processing phase, while Fig. 3 reports the knowledge representation phase in a case of deep holes for the drilling process.

\begin{tabular}{|c|c|c|c|c|c|c|c|c|}
\hline & MANUFACTURII & IG TECHNOLOGY & & MATERIA & & CAD FEATURES RE & ECOGNITION & \\
\hline $\begin{array}{c}\text { RULE } \\
\# \\
\end{array}$ & $\begin{array}{l}\text { Manufacturing } \\
\text { technology } \\
\text { class }\end{array}$ & $\begin{array}{l}\text { Manufacturing } \\
\text { technology type } \\
\text { - level 1 }\end{array}$ & $\begin{array}{l}\text { Manufacturing } \\
\text { technology type } \\
\text { - level } 2\end{array}$ & $\begin{array}{l}\text { Material } \\
\text { class }\end{array}$ & $\begin{array}{l}\text { Material } \\
\text { type }\end{array}$ & $\begin{array}{l}\text { CAD features to } \\
\text { recognize }\end{array}$ & \begin{tabular}{|l} 
PMI to \\
recognize
\end{tabular} & $\begin{array}{l}\text { Dimensions and } \\
\text { rules to verify }\end{array}$ \\
\hline 1 & Machining & Turning & Drilling & Steel & $\begin{array}{l}\text { Stainless } \\
\text { Steel - } \\
\text { AISI } 304\end{array}$ & - Hole & Roughness & 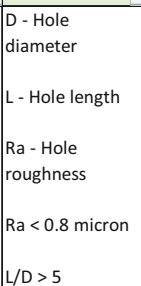 \\
\hline
\end{tabular}

Fig. 2. Example of DfMA rule collected for machining class (knowledge processing phase). 
Avoid deep holes with internal roughness $(\mathrm{Ra})$ of 0.8 micron or less. Deep holes are defined when the ratio between hole length (L) and diameter (D) is equal or bigger than 5 .

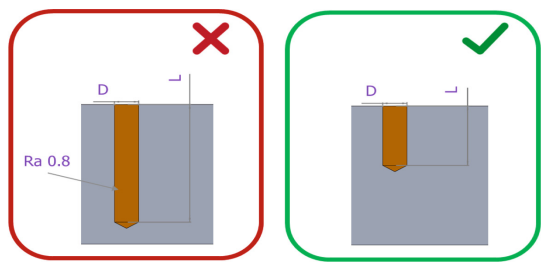

Fig. 3. Example of DfMA rule syntax and picture (knowledge representation phase).

It is worth noting that the presented approach allows checking the possibility to perform a given process for a specific technology. Thus, the validity of a rule is ensured by checking the manufacturing technology and the material classes, as well as the CAD feature recognition class. The rule model does not allow designers to verify possible investment vs. Available machines and equipment.

\section{Conclusions and Future Outlook}

This paper investigates the possibility to gather and to classify DfMA rules to create a list of design rules that can be integrated into a 3D system for the investigation of manufacturing and assembly issues early in the design step. The method is applicable in each context of manufacturing technology (i.e., machining, sheet metal stamping, metal forming, metal casting, plastic forming, welding, assembly). Furthermore, it provides a systematic approach to link product features (3D CAD model features) with manufacturing and assembly concerns early in the embodiment design. In conclusion, the method is an efficient way to collect manufacturing knowledge and to re-inject this knowledge in the development of mechanical components. In this first step of the research activity, a set of DfMA rules have been retrieved by analysing literature as well as by interviewing different manufacturing companies (internal knowledge). More rules can be defined with an efficient interview campaign and the involvement of company suppliers. The setting of further rules is the first outlook of this research work. Another significant outlook relates to the possibility of developing a software system able to integrate the retrieved DfMA design rules with a CAD tool for an efficient application of DfMA in the embodiment design phase (CAD-integrated DfMA tool).

\section{References}

1. Pahl, G., Beitz, W., Feldhusen, J., Grote, K.H.: Engineering Design: A Systematic Approach, 3rd edn. Springer, Cham (2007)

2. Ulrich, K.T., Eppinger, S.D.: Product Design and Development, 5th edn. McGraw-Hill Education, USA (2011)

3. Robertson, B.F., Radcliffe, D.F.: Impact of CAD tools on creative problem solving in engineering design. Comput. Aided Des. 41(3), 136-146 (2009)

4. Benabdellah, A.C., Bouhaddou, I., Benghabrit, A., Benghabrit, O.: A systematic review of design for X techniques from 1980 to 2018: Concepts, applications, and perspectives. Int. J. Adv. Manufact. Tech. 102(9-12), 3473-3502 (2019) 
5. De Fazio, T.L., Rhee, S.J., Whitney, D.E.: Design specific approach to design for assembly (DFA) for complex mechanical assemblies. IEEE Robot. Autom. 15(5), 869-881 (1999)

6. O'Driscoll, M.: Design for manufacture. J. Mater. Process. Technol. 122(2-3), 318-321 (2002)

7. Hoque, A.S.M., Halder, P.K., Parvez, M.S., Szecsi, T.: Integrated manufacturing features and Design-for-manufacture guidelines for reducing product cost under CAD/CAM environment. Comput. Ind. Eng. 66, 988-1003 (2013)

8. Chang, X., Rai, R., Terpenny, J.: Development and utilization of ontologies in design for manufacturing. J. Mech. Des. 132 (2010)

9. Debord, S., Segonds, F., Pinquié, R., Veron, P., Croué, N.: Proposition of a design rules framework. In: Proceedings of 25ème colloque des Sciences de la conception et de l'innovation, CONFERE 2018, Budapest, Hungary (2018)

10. Molcho, G., Zipori, Y., Schneor, R., Rosen, O., Goldstein, D., Shpitalni, M.: Computer aided manufacturability analysis: Closing the knowledge gap between the designer and the manufacturer. CIRP Ann. Manufact. Tech. 57, 153-158 (2008)

11. Boothroyd, G., Dewhurst, P., Knight, W.A.: Product Design for Manufacture and Assembly, 3rd edn. CRC Press, Boca Raton (2010)

12. Bralla, J.G.: Design for Manufacturability Handbook. McGraw Hill Professional, New York (1999)

13. Ciambrone, D.F.: Effective Transition from Design to Production, 1st edn. Auerbach Publications, Boca Raton (2007)

14. Poli, C.: Design for Manufacturing: A Structured Approach. Elsevier Science, Amsterdam (2001)

15. El Wakil, S.D.: Processes and Design for Manufacturing, 3rd edn. CRC Press, Boca Raton (2019)

16. Zhang, Z., Jaiswal, P., Rai, R.: FeatureNet: Machining feature recognition based on 3D Convolution Neural Network. Comput. Aided Des. 101, 12-22 (2018)

Open Access This chapter is licensed under the terms of the Creative Commons Attribution 4.0 International License (http://creativecommons.org/licenses/by/4.0/), which permits use, sharing, adaptation, distribution and reproduction in any medium or format, as long as you give appropriate credit to the original author(s) and the source, provide a link to the Creative Commons license and indicate if changes were made.

The images or other third party material in this chapter are included in the chapter's Creative Commons license, unless indicated otherwise in a credit line to the material. If material is not included in the chapter's Creative Commons license and your intended use is not permitted by statutory regulation or exceeds the permitted use, you will need to obtain permission directly from the copyright holder. 